\title{
THE LABOUR CHURCHES AND NEW ZEALAND
}

The British Labour Church movement which was discussed by Mr. K. S. Inglis in a recent article ${ }^{1}$ is of some importance to New Zealand for two reasons. A native New Zealander, H. A. Atkinson, was one of the early leaders of the movement in Britain, and he later introduced the idea of the Labour Church to New Zealand and formed the first openly socialist organisation in this country.

Harry Albert Atkinson was born in 1867 and was named after his uncle, Sir Harry Atkinson, who was Premier of a conservative government in 1884 and again from I 887 until I $89 \mathrm{r}$. Like so many New Zealanders, the young man was caught up in the "wave of socialistic feeling" ${ }^{2}$ which swept over New Zealand in the late eighties. The immediate influence on young Atkinson's thinking came from F. W. Frankland, a son of Sir Edward Frankland, F.R.S., who was New Zealand Government Life Commissioner and Actuary. Frankland had met Herbert Spencer and other British radicals before coming to New Zealand. He maintained his membership of the Fabian Society, and he gathered at his home in Wellington a group of young people for the discussion of social problems.

Early in 1890 , Harry Atkinson helped to form an Engineers' Union in Wellington but later that year he sailed for England. He obtained work as a draughtsman in Manchester and it was there that he met John Trevor and soon became his devoted follower.

Atkinson took a leading part in the work of the Manchester and Salford Labour Church and, in December I 891, he was appointed General Secretary. It is no doubt correct, as Mr. Inglis has pointed out, that Trevor was always more interested in spiritual aims than in work for

1 K. S. Inglis. The Labour Church movement. International Review of Social History, v. 3, pt. 3, 1958. p. $445-460$.

2 W.P. Reeves. State experiments in Australia and New Zealand. London, 1902, v. I, p. 74. 
social reform. In its first year, however, the Manchester Labour Church engaged actively in local economic struggles.

Trevor himself visited the Bronsgrove nailers and described their wretched conditions in the Labour Prophet. When the Manchester mat makers went on strike (two of the strikers were members of the Labour Church) Trevor, and later Atkinson, became treasurer of the strike fund and, for fifteen weeks, collections in aid of the strike were taken at the Labour Church. Atkinson also became treasurer of the Mat Makers' Union which was formed as a result of the strike, and he assisted with the establishment of a Mat Makers' Co-operative Society in June 1892 .

Following a successful May Day demonstration in Manchester in 1892, Trevor, Blatchford, Atkinson, and four other delegates met in the Clarion office and adopted a constitution for a Manchester and Salford Independent Labour Party which included the much-discussed fourth clause pledging members not to vote for any Liberal, Liberal-Unionist, or Conservative candidate. Other I.L.P. branches were formed in the months that followed and a national Independent Labour Party was established at a conference in January 1893. It rejected the Manchester Fourth Clause after a long debate.

In July 1893, Atkinson was one of the delegates at the inaugural conference of the Labour Church Union but later that year he returned to New Zealand where he took employment in the Addington Railway Workshops in Christchurch.

Atkinson had left New Zealand in I 890 imbued with vague ideas of social reform such as were then fashionable in middle-class circles. He returned three years later a convinced socialist. He lectured on his experiences with the Labour Church in Wellington and Christchurch and, in October 1896, he thought the time ripe to form a similar organisation in this country.

It is significant that Atkinson called the new organisation not a Labour Church but a Socialist Church. There were other radical groups then in existence - a Clarion Club in Wellington and a Fabian Society in Dunedin - but only Atkinson's Christchurch Socialist Church proclaimed itself openly as a socialist organisation.

Albert Métin who visited New Zealand in 1899 , reported: "A Christchurch (Nouvelle-Zélande) un jeune mécanicien, récemment émigré d'Angleterre, essaie de faire un peu de propagande; il est vaguement socialiste chrétien, il a fondé un petit groupe appelé Socialist Church (Église Socialiste). 'Église', me dit-il, 'fera passer l'épithète, car ici les ouvriers sont très pieux et ils ont une grande défiance du Socialisme." "

And Métin went on to add: "Je m'en suis bien aperçu moi-même, à 
la surprise que j'ai causée, dans la Bourse du travail de Christchurch, en déclarant que beaucoup de grands syndicats français s'affirmaient socialistes. Le socialisme, tel que nous le connaissons, n'est guère representé en Australasie que par de petites sociétés qui travaillent activement à pénétrer le mouvement ouvrier mais qui restent en dehors des organisations ouvrières".1

Atkinson, when his attention was drawn to this passage in 1954, was quite emphatic that Métin must have misunderstood him. "I should not have had the courage to start anything had I not been in touch with Trevor", he wrote, "in running his whole Labour Church movement in England in $189 \mathrm{I}-2$, the first year of its existence. Like Trevor, I was imbued with the idea that it was important to recognise that in itself the effort for betterment inherent in the labour movement was religious. Trevor called it God in the Labour Movement. I did not express myself that way, but the feeling was similar, that the movement was deeply and in a very real sense religious... Trevor had argued the case out with himself as to whether it should be a Socialist Church or a Labour Church and chose what he considered the wider term. In my effort here I plunged for the term Socialist. The word 'church' was not added, it was fundamental as embodying the religious ideal". ${ }^{2}$

The objects of the Christchurch Socialist Church were defined as follows:

"The Socialist Church aims at promoting a fellowship amongst those working for the organisation of Society on a basis of Brotherhood and Equality.

It affirms the Principle that only as we learn to lead purer and better lives can we benefit by any measures of Social Reform.

It does not pretend to satisfy the whole religious wants of any person, but is founded in the belief that its principles are such as should form an integral part of every man's Religion". ${ }^{3}$

Members met weekly, first at the Atkinsons' house and then, as attendances grew, in hired rooms. The meetings bore little resemblance to church meetings. They took place on week nights and were concerned with the discussion of topics such as "Why We Want Equality" or "Human Nature and Socialism" which were introduced by advertised speakers. The only seemingly religious feature was the singing of Labour Hymns, and the Church published a Hymn Sheet copied largely from the similar sheets published in Manchester.

Each Sunday afternoon, Atkinson took the stump in Cathedral Square, the traditional spot for outdoor oratory in Christchurch. It

\footnotetext{
1 A. Métin. Le socialisme sans doctrines. 2. éd. Paris, IgIo. p. I 7 .

2 Letter from H. A. Atkinson to H. Roth, of 17 th February 1954.

8 Socialist Church. Monthly leaflet. no. I. Feb. 1897.
} 
was through these outdoor meetings that he gained the most valuable recruit to the Church, J. A. McCullough, a leading trade unionist.

Another activity of the Church was the importation of socialist literature - the Labour Prophet and Clarion and numerous pamphlets. A monthly leaflet was published from February 1897 onwards and was distributed free. In August 1897, this was replaced by a regular journal, the Socialist. Here, for the first time, the idea of an independent labour party for New Zealand was put forward:

"The organisation of an Independent Socialist party, keeping itself entirely distinct from either existing political party, and throwing its weight in a block vote according to the manifestations of either Liberal or Conservative to proceed in the right direction, would give a great spurt to political and social progress. As this third party gained strength, it could run its own parliamentary and municipal candidates, which would be an immense advantage to the 'cause', not only by obtaining representation, but also for purposes of education and propagandism". ${ }^{1}$

Ben Tillett who visited New Zealand in 1897 , wrote for the Socialist and his lecture to the Socialist Church was published as a pamphlet "Socialism, Being an Address to Comrades". Tillett spoke out strongly against the various theories which were then competing with socialism for the attention of New Zealand workers - the single tax, utopianism (such as Lane's "New Australia" settlement in Paraguay) and, most important, the so-called State Socialism of the Seddon Government.

"You people in New Zealand", said Tillett, "who talk about the Socialism of your legislation, have, as a matter of fact, not got Socialism; and how you ever came to believe that you had, I do not know. You have yet to make your Socialism - that is the position you are in". 2

Under the inspiration of 'Tillett's visit, a Socialist League was formed in Wellington and affiliation with the Socialist Church in Christchurch was discussed. Membership was small, however. As Atkinson reported in the Labour Annual for 1899: "Socialism as such is not numerically strong. It is represented by a Socialist League in Wellington, a Socialist Church in Christchurch, and Fabian Societies in Dunedin and Christchurch, with a total membership not exceeding 250 ". 3

The Socialist was forced to cease publication in January 1898 , and the Boer War which was supported enthusiastically by the Seddon Government added to the difficulties of the socialist societies. The

1 Socialist. v. I, no. I. Aug. 1897.

2 B. Tillett. Socialism. Christchurch, 1897. p. Io.

3. A. Atkinson. Social reform in New Zealand, in: Labour annual. London, 1899, p. 48. 
Socialist Church opposed the war, holding that Britain should redress the grievances of her own people before interfering in the Transvaal. It also protested against the victimisation of government and municipal employees who had spoken out against militarism.

The minute books of the Socialist Church for I $900-190$ I have survived in part, and they show that discussion at the fortnightly meetings was concerned largely with local questions: the drawing up of a municipal programme, papers on "What a Councillor Might Do", and compilation of a questionnaire for parliamentary candidates. Currency reform and Co-operation were other questions discussed, and resolutions passed by the Church were regularly published in the local press. A visit to New Zealand by Keir Hardie was expected, and the Church drew up a statement on the political situation in New Zealand for Hardie's information. This visit failed to take place (Hardie did not come to New Zealand until 1907) but almost two hundred Clarion settlers led by W. R. Ranstead arrived late in 1900 , and the Socialist Church arranged a reception in their honour.

Thanks to the initiative of these Clarion settlers, a Socialist Party was formed in Wellington in I901. The Christchurch Socialist Church was anxious to co-operate with it but was not willing to merge its identity and become a branch of the new party. Atkinson was at all times more concerned with educational propaganda work than with electoral activity which he thought premature in New Zealand.

The Socialist Church survived the first attempt to form a Socialist Party branch in Christchurch but in the long run there was not room for two socialist organisations in the city. In September 1904, the Socialist Party branch was revived and, soon afterwards, the Socialist Church faded out of existence. It last appeared before the public in May 1905 when it organised a meeting on "Municipal Enterprise" which was addressed by a local member of parliament.

Throughout the almost ten years of the Church's existence, H. A. Atkinson was its secretary and guiding spirit. Although we must accept his statement that to him the religious aspect was always as important as the socialist, the fact remains that the Socialist Church was a church in name only. It was a propaganda organisation which differed only slightly from the socialist leagues or Fabian Societies in other centres. In fact, when Atkinson revived the group in 1908, he chose the name Canterbury Fabian Society.

Membership of the Socialist Church was always small but it was able to make its influence felt throughout Christchurch, for its members were active on a variety of bodies - trade unions and the Trades Council, the Canterbury Women's Institute, the Progressive Liberal Asso- 
ciation, prohibition groups and the Charitable Aid Board. Among members of the Church who later became prominent in the New Zealand labour movement were J. A. McCullough, workers' representative on the Court of Arbitration from 1908 to 1922 and a member of the Legislative Council from 1935 to 1947, James Thorn, a Labour M. P. from I 935 to 1946 who was president of the Economic and Social Council of the United Nations in 1949, James McCombs, Labour M. P. from 1913 to I933, and his wife, Mrs. Elizabeth McCombs, who was New Zealand's first woman M. P. from 1933 to her death in 1935 .

The Christchurch Socialist Church is significant in the history of the New Zealand labour movement not only as the only local example of a Labour Church but also as the first openly socialist organisation in this country. Like the Fabian Society which succeeded it, it was able to introduce a number of middle-class people and intellectuals to socialist ideas and thus helped to impart to the Christchurch labour movement its unique flavour, which was at once its strength and its weakness. 